\title{
The Influence of Techniques of Larvae Rearing and Seed Collectors on the Survival Rate and Recovery Efficiency of the Brown Mussel Perna perna (L.) in Laboratory
}

\author{
Pedro Beduschi ${ }^{1}$, Cláudio Manoel Rodrigues de Melo ${ }^{2}$ and Jaime Fernando Ferreira ${ }^{2 *}$ \\ ${ }^{1}$ Universidade Federal de Santa Catarina; Florianópolis - SC - Brasil. ${ }^{2}$ Departamento de Aqüicultura; \\ Universidade Federal de Santa Catarina; C.P.: 476; 88040-900; Florianópolis - SC - Brasil
}

\begin{abstract}
Te study compared the hatchery recovery efficiency and survival rate of Perna perna spats using larvae submitted to four conditions, prior to settlement, tested with for different collectors. In 15 days old larvae (eyed larvae, T1), transparent nylon thread collectors presented the best results for spats recovered per meter of collector. The 28 days old larvae (foot larvae) stored under refrigeration before settlement (T3 with water and T4 without water) showed no significant differences between the spat number in all the collectors. The brown multi-thread collector was more efficient in $T 4$. The blue polyamide thread collector was the most efficient with 28 days old larvae settled directly, without refrigeration (T2). Treatment 1 showed the highest spats recovery percentage in the collectors $(89.44 \%)$ in relation to the tank wall. The results showed that the efficiency of the collector depended on the methodology to prepare the larvae and the material used in the collector.
\end{abstract}

Keywords: spats, settlement, Perna perna, collectors, hatchery

\section{INTRODUCTION}

Production of Perna perna mussel spats in laboratory based on induced spawning and larvae rearing until settlement is the most efficient method, with guaranteed production and less impact on natural stocks (Ferreira and Magalhães, 2004). Nevertheless, such method demands investment in equipment and specialized staff, further to a large production area to meet the current demands. An alternative would be the production of larvae to be settled in the culture sites by the producers through remote settling. To meet this purpose, it is essential to know that settlement process in spat collectors that can be regularly used by mussel farmers.

In Brazil, $P$. perna reproduces several times a year, with high spawning capability in certain seasons (Lunetta, 1969). In Santa Catarina state summer and spring are the best seasons to collect the spats (Ferreira and Magalhães, 2004) and, in São Paulo state, the best period is between September and December (Marques, 1987). Larval density in the plankton is the highest in these seasons. When they reach the plantigrade stage (about $1 \mathrm{~mm}$ of length) they are ready to search for a substrate, settle and undergo the last metamorphosis.

\footnotetext{
* Author for correspondence: jaime.ferreira@pq.cnpq.br
} 
Mussels from the genus Mytilus firstly settle on a filamentous substrate and then on a definite substrate in a process known as primary/secondary settlement (Bayne, 1964). Such larval behavior avoids competition with adults and after the growth period, the larvae would enter a secondary pelagic phase and migrate to settle definitely in the mussel beds.

Snodden and Roberts (1997) studied the Mytilus edulis settlement pattern in two distinct sites and reported both the existence of a direct settlement in mussel beds and also a secondary settlement, as they found individuals belonging to three different size classes on the sites. The same pattern was observed by Cáceres-Martinez et al. (1993) with Mytilus galloprovincialis settled on the rocks and nylon ropes. They found individuals coming directly from the plankton $(<0.5 \mathrm{~mm})$ to the rocks, without a previous growth phase on another substrate, and a large number of secondary individuals $(>0.5 \mathrm{~mm})$ on the nylon collectors, which corroborated with Bayne (1964), who reported the ability of just-settled larvae to "attach and detach" several times before settling definitely.

Other studies have also shown post-larvae of $M$. galloprovincialis $(<0.470) \mathrm{mm}$ on filamentous collectors on the adults of the same species and on algae, indicating direct settlement on such substrates. Cáceres-Martinez et al. (1994) and Ramírez and Cáceres-Martinez (1999) observed that many larvae even grew on the collectors while they remained in the water. For Perna perna, Lasiak and Barnard (1995) reported direct larvae settlement from the plankton onto the adult mussel beds and, in some instances, a temporary settlement in filamentous algae.

In laboratory, primary settlement of Perna canaliculus was high on hydroids (Amphisbetia bispinosa) and on algae (Corallina officinalis, Champia laingii and Laurencia thyrsifer). In field, most of the recruited individuals were large and coming from a secondary settlement (Buchanan and Babcock, 1997).

Existence of different settlement patterns in mussels can be explained by the genotypical variation between the species (Cáceres-Martinez et al. 1993), and also by the peculiar ecological conditions of each environment.

Mussels settlement and growth are influenced by the increase in water flow, probably due to the increased food propagation and flow with increase in water speed (Rajagopal et al., 1998). Perna canaliculus larvae settlement and juvenile resettlement increased with increased water flow and increase in the oxygen concentration also enhanced larvae settlement, but not of juveniles. In addition, mortality of larvae and juveniles decreased with higher water flow after $24 \mathrm{~h}$ in experimental tanks (Alfaro, 2005).

For $P$. perna, further research is required in settlement phases, such as ideal age that larvae should be transferred to settlement tanks, ideal substrate for larvae settlement, larval density and feeding, ideal length of time in tanks before transferring to sea, etc.

In order to contribute to the development of technologies for the production of $P$. perna mussel spats in laboratory, this study aimed to compare the efficiency and survival of mussels of three sizes $(500,1,500$ and $3,000 \mu \mathrm{m})$ in different experimental situations of larvae preparation for settlement and in different types of collectors.

\section{MATERIALS AND METHODS}

\section{Larvae}

Larvae were obtained by inducing to spawn sexually mature mussels, with $80 \mathrm{~mm}$ of length, stage of gonad development IIIA (Lunetta, 1969). They were taken from the Marine Molluscs Laboratory culture site at Sambaqui beach at Florianópolis/SC - Brazil ( $27^{0} 35^{\prime} \mathrm{S}$ and $\left.48^{0} 32^{\prime} \mathrm{W}\right)$. Density in the tanks was 4 larvae $\mathrm{mL}^{-1}$ (Farias, 2005), in a total of c.a. 1,600,000 larvae in each tank of treatments 1 and 2, and 360,000 larvae in each tank of treatments 3 and 4 . Water was changed every 24 hours and larvae were retained in $35 \mu \mathrm{m}$ mesh screen and returned to the same tanks.

Tanks were aerated using laboratory blowers and aeration stones for good oxygenation and water flow.

During the first 15 days, larvae were siphoned from the bottom of the tanks. Larvae were fed a diet composed of $70 \%$ Chaetoceros muelleri and $30 \%$ Thalassiosira pseudonana (clone 3H) + Isochrysis sp. (T-iso) + Skeletonema sp. In the first 20 days, microalgae were fed once a day at a concentration of $4 \times 10^{4}$ cells $\mathrm{ml}^{-1}$ and increased gradually up to $12 \times 10^{4}$ cells $\mathrm{ml}^{-1}$ twice a day. Antibiotics $\left(1.5 \mathrm{mg} \mathrm{L}^{-1}\right.$ chloramphenicol and 0.5 $\mathrm{mg} \mathrm{L}^{-1}$ furazolidone) were added every $24 \mathrm{~h}$ during water change to secure mussel survival until the end of the experiment. 


\section{Experimental set-up}

The study consisted in comparing the mussels settlement efficiency and survival during two months in four experimental set-ups (treatments), as follows:

T. 1 - mussel larvae were transferred to the settlement tank as soon as they developed the eye spot ( $15^{\text {th }}$ day after spawning);

T. 2 - larvae were transferred to the settlement tanks with 28 days of age, when foot was totally developed and they were forming clumps in the larvae culture tanks;

T. 3 - 28 days old larvae were stored refrigerated $\left(10{ }^{\circ} \mathrm{C}\right)$ for $24 \mathrm{~h}$ in a $125 \mu \mathrm{m}$ mesh net in a one liter Beaker glass with water before transference to the tanks;

T. 4 - 28 days old larvae were stored refrigerated $\left(10{ }^{\circ} \mathrm{C}\right)$ for $24 \mathrm{~h}$ in a $125 \mu \mathrm{m}$ mesh net in a one liter Beaker glass without water before transference to the tanks.

Four tanks were used, one for each treatment. A $2 \times 1 \mathrm{~m}$ tanks with $400 \mathrm{~L}$ capacity were used for treatments 1 and 2 , and $0.85 \times 0.55 \mathrm{~m}$ tanks with 90 L capacity were used for treatments 3 and 4 . Firstly, tanks were disinfected with lemon juice and sun exposition. Collectors were left in a 200 ppm chlorine solution for $24 \mathrm{~h}$ before the use. The collectors were then left in tanks with seawater for five days for biofilm formation.

In all the treatments, four types of collectors were tested. Three of them were made manually with fishing materials, which were blue polyamide net (MA), brown multi-filamentous polyethylene net (MM) and transparent polypropylene net (NY). The forth collector was made of black polypropylene (NZ), known as "Christmas tree", a New Zealander model, manufactured in Brazil by Mazzaferro Industry. Ten $1 \mathrm{~m}$ long collectors of each type were put in the tanks of experiments 1 and 2. In experiments 3 and 4 , five $0.5 \mathrm{~m}$-long collectors of each type were used. As collectors were of different sizes and in different quantities, data were normalized for $1.0 \mathrm{~m}$ length and 10 collectors per treatment for the statistical analysis. Mussel recovery rates were obtained by multiplying the number of individuals (on the collector and/or bottom) by 100 and dividing by the total starting number of larvae in each situation.

By the end of each experimental procedure, collectors were submerged in a 5\% Sodium Hypochlorite solution to separate the mussels from collectors (Araújo, 1994). Mussels settled in the bottom of the tanks were also collected. Next, they were fixed in $4 \%$ formalin for $24 \mathrm{~h}$ and then transferred to $70 \%$ alcohol.

Mussels were then screened and divided into three sizes $(500,1,500$ and 3,000 $\mu \mathrm{m})$. Samples were counted according to treatment, size and collector.

\section{Statistical analysis}

Data were analyzed at 5\% level of significance. ANOVA was used to compare the amount of mussels settled in the different collectors of each treatment and per type of collector. If significant and the variances showed to be homogeneous, average analysis according to Tukey test was applied using Statistica ${ }^{\circledR}$ software program. For the other results, only descriptive statistical analysis were done.

\section{RESULTS}

About 394,600,000 oocytes were obtained from spawning, of which $161,333,320$ resulted in Dlarvae 24 hours after fertilization, representing a $40 \%$ yield in this phase of the hatchery. Of these only 50,000,000 were used in the experiments.

Table 1 presents the mean and standard deviation of the number of mussels removed from the collectors in the different experimental situations.

In $\mathrm{T} 1$, in which larvae were transferred to the settlement tanks as soon as they became eyed and still free-swimming, the transparent collector (NY) presented the best result with recovered mussels (879.9) being statistically higher when compared with the other materials tested. In T2, in which larvae were transferred at 28 days of age, already footed and ready to settle, the number of mussels in the New Zealander model (NZ) was statistically lower than the others. In T3 and T4, in which 28 days old larvae were kept refrigerated with and without water, respectively, $24 \mathrm{~h}$ before transfer, there was no significant difference between the number of mussels in the collectors in any of the situations.

In this study, the highest amount of mussels per meter of collector was $2,093.60 \pm 614.22$ spats $\mathrm{m}^{-1}$ and occurred in the treatment where larvae were transferred at 28 days of age, refrigerated without water, with foot totally developed and using brown

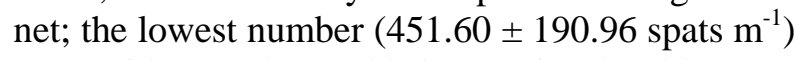
was with 15 days old larvae in the blue net collector. 
Analyzing the number of individuals settled in the brown net collector (MM), there was significant difference $(\mathrm{p}<0.05)$ in all the treatments. It was more efficient when used in footed larvae kept refrigerated for $24 \mathrm{~h}$ without water (T4). In the blue net collector (MA), the results for footed larvae (T2,T3 and T4) presented no differences and the least efficient was obtained in and eyed larvae (T1). Comparing the transparent net (NY) and the New Zealander model (NZ), best results were detected in footed larvae (T3, T4).

The transparent collector (NY) presented the best performance in all the treatments (Table 1).

Table 2 presents the relative mussel recovery (\%) in the collectors and in the bottom, further to the final survival percentage in each treatment.

Table 1 - Mean and standard deviation of the number of spats obtained per meter of collector, in the different treatments.

\begin{tabular}{|c|c|c|c|c|c|}
\hline \multirow{2}{*}{ Treatment } & \multicolumn{5}{|c|}{ Type Collector } \\
\hline & & MM & MA & NY & $\mathbf{N Z}$ \\
\hline \multirow{2}{*}{ T1 (eyed larvae) } & \multirow{2}{*}{ mean std. dev. } & $601.3^{\mathrm{a}}$ & $451.60^{\mathrm{a}}$ & $879.9^{b}$ & $526.00^{\mathrm{a}}$ \\
\hline & & \pm 149.66 & \pm 190.96 & \pm 251.55 & \pm 256.04 \\
\hline \multirow{2}{*}{ T2 (footed larvae) } & \multirow{2}{*}{ mean std. dev. } & $940.7^{\mathrm{a}}$ & $1,080.30^{\mathrm{a}}$ & $1,015.90^{\mathrm{a}}$ & $623.40^{\mathrm{b}}$ \\
\hline & & \pm 133.70 & \pm 189.40 & \pm 250.98 & \pm 163.74 \\
\hline \multirow{2}{*}{$\begin{array}{c}\text { T3 (footed larvae, } 24 \\
\text { h refrigeration) }\end{array}$} & \multirow{2}{*}{ mean std. dev. } & $1,139.20^{\mathrm{a}}$ & $1,390.40^{\mathrm{a}}$ & $1,697.60^{\mathrm{a}}$ & $1,148.00^{\mathrm{a}}$ \\
\hline & & \pm 257.33 & \pm 131.59 & \pm 469.91 & \pm 496.87 \\
\hline \multirow{2}{*}{$\begin{array}{c}\mathrm{T} 4 \text { (footed larvae, } 24 \\
\text { h refrigeration) }\end{array}$} & \multirow{2}{*}{ mean std. dev. } & $2,093.60^{\mathrm{a}}$ & $1,395.20^{\mathrm{a}}$ & $2,064.00^{\mathrm{a}}$ & $1,364.80^{\mathrm{a}}$ \\
\hline & & \pm 614.22 & \pm 393.71 & \pm 762.44 & \pm 746.92 \\
\hline
\end{tabular}

Note: superscript letters represent statistical difference $(\mathrm{p}<0.05)$ for the different collectors, in each experimental condition.

Table 2 - Final survival percentage and relative number of mussels recovered in the collectors and in the bottom of the tank (in relation to the initial number of larvae in the tanks) in the different treatments.

\begin{tabular}{|c|c|c|c|}
\hline Treatment & Final Survival (\%) & $\begin{array}{c}\text { Recovery in the collectors } \\
(\%)\end{array}$ & $\begin{array}{c}\text { Recovery in the bottom } \\
(\%)\end{array}$ \\
\hline T1 (eyed larvae) & 1.72 & 1.53 & 0.18 \\
\hline T2 (footed larvae) & 3.26 & 2.28 & 0.97 \\
\hline $\begin{array}{l}\text { T3 (footed larvae, } 24 \mathrm{~h} \\
\text { refrigeration in water }\end{array}$ & 2.86 & 1.86 & 1.00 \\
\hline $\begin{array}{l}\mathrm{T} 4 \text { (footed larvae, } 24 \mathrm{~h} \\
\text { refrigeration without water }\end{array}$ & 3.31 & 2.40 & 0.91 \\
\hline
\end{tabular}

Figure 1 shows the relative quantity of animals obtained in the collectors and in the bottom of the tanks in relation to the total number of animals recovered, and the total sum of mussels recovered in each experiment.

Treatment 2 (footed larvae) had 3.26\% survival and the highest recovery rate. A total of 52,094 mussels were counted in this treatment, of which $70.26 \%$ were found in the collectors and $29.74 \%$ in the bottom of the tank. Treatment 1 (eyed larvae) had the highest recovery rate in the collectors $(89.44 \%)$ and lower percentage of individuals in the bottom $(10.56 \%)$, when compared to the other experiments, with a total survival of $1.72 \%$. Treatment 3 and 4 presented similar results, and survival rates of 2.8 and $3.31 \%$, respectively. Treatments 2,3 and 4 presented the highest total recovery rates however with higher rates of mussels in the bottom.
Figure 2 shows mussel counting after the experiments. In all the treatments, the number of mussels retained in the $500 \mu \mathrm{m}$ screen was higher than in the other sizes. Compared to the others, in $\mathrm{T} 1$, there were more mussels retained in the 3,000 $\mu \mathrm{m}$ screen $(11.22 \%)$ and in the $1,500 \mu \mathrm{m}$ screen (42\%). In T3 and T4 the highest numbers of mussels were found in the $500 \mu \mathrm{m}$ screen $(75.23 \%$ in $\mathrm{T} 3$ and $71.31 \%$ in $\mathrm{T} 4$ ).

Figure 3 compares the relative amount of mussels retained in the $3,000 \mu \mathrm{m}$ screen, considering the data for each type of collector in the different treatments. Brown net (MM) and blue net (MA) collectors were the substrata that presented the highest percentages in the $3000-\mu \mathrm{m}$ screen. The lowest percentage was found in the NewZealander type (NZ). 


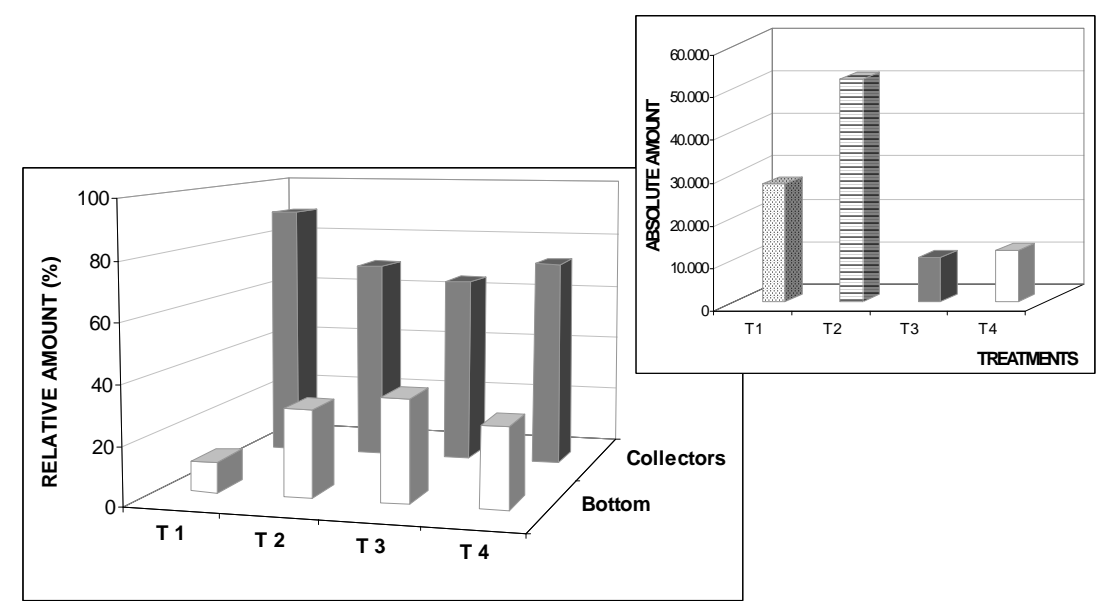

Figure 1 - Relative amount (\%) of mussels settled in the collectors and in the bottom, according to the total of mussels recovered in each treatment. In the small box, absolute amount of mussels recovered in each treatment.

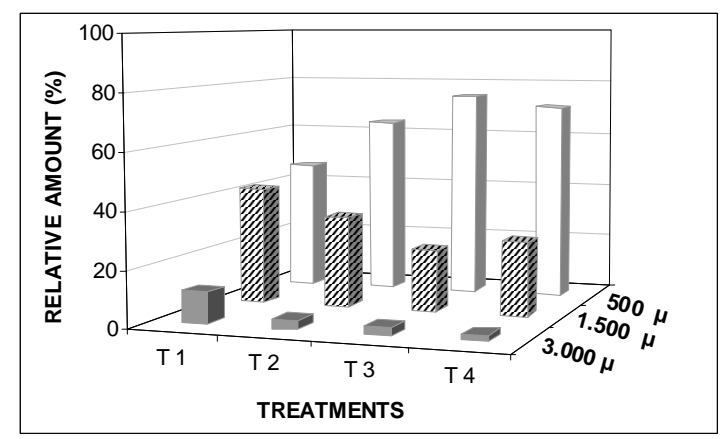

Figure 2 - Relative amount (\%) of mussels separated by size, at the end of the experiment.

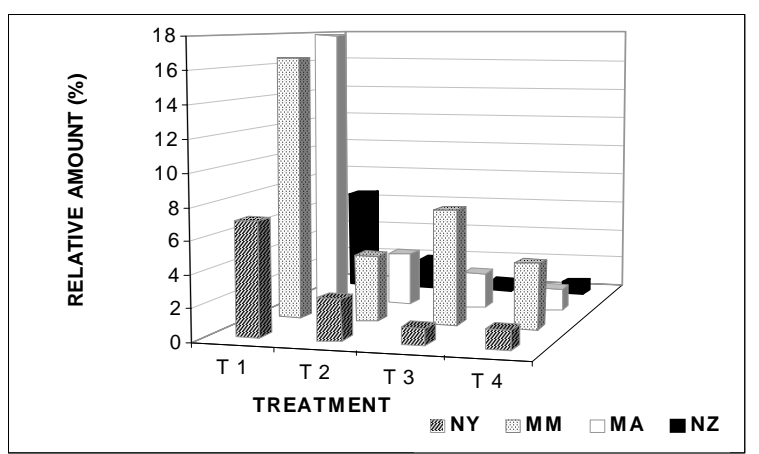

Figure 3 - Comparison of the relative amount (\%) of mussels retained in the $3000-\mu \mathrm{m}$ screen, considering the data for each type of collector, in the different experiments. 


\section{DISCUSSION}

Several species of mussels settle intensely on filamentous substrata (Bayne 1964; Lasiak and Barnard, 1995; Pulfrich 1996; Buchanan and Babcock, 1997; Alfaro and Jeffs, 2003; Wlater and Liebezeit, 2003). According to Seed (1976), such preference is more related to their morphology rather than to any other chemical attraction. Furthermore, bivalve mollusks can have their settlement influenced by water hydrodynamics around the collectors (Eyster and Pechenik, 1987; Alfaro, 2005) and by the existence of primary colonies or biofilm (FAO, 2004).

Cáceres-Martinez et al. (1994) studied the settlement of Mytilus galloprovincialis using filamentous nylon ropes as the collectors. Highest settlement occurred in the open sea with almost 60,000 mussels $\mathrm{m}^{-2}$ after five months. However, in the collectors left for shorter periods in the sea or in different months, less than 500 mussels $\mathrm{m}^{-2}$ were settled. In New Zealand, for Perna canaliculus, the "Christmas tree" collector had 4,056 mussels $\mathrm{m}^{-1}$ in the best month of attachment and 122 mussels $\mathrm{m}^{-1}$ in the worst month for mussels smaller than $0.49 \mathrm{~mm}$. For mussels larger than $1.0 \mathrm{~mm}, 1,712$ mussels $\mathrm{m}^{-1}$ and 1,282 mussels $\mathrm{m}^{-1}$ were found in the best and worst months, respectively (Alfaro and Jeffs, 2003).

Walter and Liebezeit (2003) analized 5 types of collectors in a highly dynamic tidal environment and observed a high number of Mytilus edulis mussels settled after 5 months of submersion. The most efficient was the industrial filamentous polypropylene type with 16,235 spats $\mathrm{m}^{-1}$ and the worst type was the handmade filamentous polypropylene, with 3,959 spats $\mathrm{m}^{-1}$. CácerezMartinez et al. (1994) tested M. galloprovincialis settlement preference in laboratory with different substrata (algae Ceramium rubrum, byssal filaments, scotchbryte nylon net) and concluded their preferences for Ceramium rubrum and byssal filaments.

Larval density was instantaneously higher in the laboratory tanks (4 larvae $\mathrm{ml}^{-1}$ ) than in the wild. Vooys (1999) found for M. edulis density of about 18,000 larvae in $100 \mathrm{dm}^{3}$, whereas Bayne (1964) found 700 larvae $(>250 \mu \mathrm{m}) \mathrm{m}^{-3}$ and Helson and Gardner (2004), 4,207 larvae $\mathrm{m}^{-3}$. Nevertheless, the higher number of spats found in studies in the wild than in laboratory can be related to the constant settlement of plantigrades in the collectors. In the wild, the number of available larvae is not restricted only to a single spawn and can accumulate in successive spawns that occur during hours or even days.

In this study, the highest number of mussels $\left(2,093.60 \pm 614.22\right.$ spats $\left.\mathrm{m}^{-1}\right)$ occurred in the experiment in which footed larvae were transferred to the settlement tanks with 28 days of age, refrigerated without water, using brown net collector. The lowest number $(451.60 \pm 190.96$ spats $\mathrm{m}^{-1}$ ) occurred in the blue net collector using 15 days old larvae.

Several studies have indicated the increase in mussel settlement with increased water flow (Eyster and Pechenik, 1987; Rajagopal et al., 1998; Alfaro, 2005), as it would increase the chance of the larvae to successfully find the substrate. Cácerez-Martinez et al. (1994) tested settlement in two different conditions: still water and flowing water. Settlement in flowing water was statistically higher $(p<0.001)$ than in still water. In still water, larvae did not prefer any type of substrate and remain scattered in the bottom. They also reported that larvae would remain in the first site of attachment if undisturbed, which was also seen in the present study. Thus, lack of adequate water flow in the experimental laboratory tanks could have influenced the settlement in the bottom.

These results showed that in the experiments with 28 days old larvae (ready to settle), there was higher settlement in the bottom, whereas in the experiments with 15 days old larvae (eyed but still free-swimming), they settled more in the collectors.

Just-settled mussels (250-300 $\mu \mathrm{m})$ have the ability to "attach and detach" several times until final settlement in a substrate (Bayne, 1964). Alfaro (2005) reported that mussels selected settlement substrate because they were able to detect chemical and tactical stimuli. The higher settlement percentage of mussels in the collectors from T1 (eyed larvae) (Fig. 1) could be attributed to the fact that they were still free-swimming when put in the tank, thus, more able to select the ideal site for settlement with more time. However, some authors disagreed of such selective behavior. Cáceres-Martinez et al. (1994) proposed that mussel settlement resulted from the contact of the mucous filament of pediveliger and post-larvae with the substrate, which could be provided only by hydrodynamic processes. Harvey and Bourget (1995) propose that the preference could result from the passive deposition of the larvae onto the 
substrate, due to its heterogeneous filamentous structure.

Just-settled invertebrates are usually subject to high mortality rates (Hunt and Scheibling, 1997). In mussels, survival until the end of metamorphosis is low most of the times (Waterstrat et al., 1980 apud Trevelyan, 1991). This corroborated with the survival rates found in the present study - low in all experiments. But Trevelyan (1991) found $78 \%$ of survival rate after 30 days for $M$. edulis post-larvae $(0.5 \mathrm{~mm})$ culture. Growth rates are optimized according to food concentration and quality (Pechenik et al., 1990), and also to water flow as a result of a increased flow of food (Rajagopal et al., 1998).

In the experiments where larvae were kept refrigerated before taken to the settlement tanks, the highest amount of mussels was ound retained in the smaller mesh screens. Trevelyan (1991) kept $M$. edulis larvae refrigerated $\left(5^{\circ} \mathrm{C}\right)$ for $48 \mathrm{~h}$ and this did not affect either settlement or swimming behavior. Farias (2005) observed that Perna. perna larvae kept refrigerated $\left(10{ }^{\circ} \mathrm{C}\right)$ for $72 \mathrm{~h}$ presented settlement rates of $71 \%$ and $43.5 \%$ and suffered metamorphosis in 15 days of experiment. However, none of these studies reported a control treatment to compare the mentioned results. Using that methodology for oysters, Holiday et al. (1991) emphasized that settlement was excellent (77$85 \%$ ) for Saccostrea commercialis kept at $11{ }^{\circ} \mathrm{C}$ for 98 h, and for Crassostrea gigas (68\%) kept at 6 ${ }^{\circ} \mathrm{C}$ for $98 \mathrm{~h}$.

The present results showed that the efficiency of the collector depended on the methodology in preparing the larvae for settlement. To obtain larger individuals, the best condition was using 15 days old larvae for settlement in brown nylon and blue net collectors. For the number of mussels, the best was to use 28 days old larvae, refrigerated without water for $24 \mathrm{~h}$ (T4) using brown and transparent nylon collectors.

An alternative to improve the recovery rates would be to input larvae successively in the settlement tank, which would promote new settlement cycles in that same collectors.

Since individuals presented low growth and high food intake, an alternative would be to produce larvae in laboratory and, after settlement, transfer them immediately to the sea or yet, settle them at the culture sites via remote settling.

\section{RESUMO}

Comparamos a eficiência de recuperação e sobrevivência em laboratório de pré-sementes de Perna perna utilizando larvas submetidas a 4 situações de preparação, antes do assentamento, testadas em 4 diferentes coletores. Em larvas de 15 dias (com olho, T1), coletores de rede de nylon transparente apresentaram os melhores resultados de recuperação de indivíduos por metro de coletor. Larvas de 28 dias (com pé), mantidas em condições de resfriamento antes do assentamento (T3 com água e T4 sem água) não apresentaram diferença significativa no número de animais recuperados em todos os coletores. O coletor de rede de polietileno marrom foi mais eficiente no T4. O coletor de rede de poliamida azul foi mais eficiente com as larvas de 28 dias, colocadas diretamente para assentar, sem resfriamento (T2). $\mathrm{O}$ tratamento $\mathrm{T} 1$ foi o que apresentou o maior percentual de eficiência de recuperação nos coletores $(89,44 \%)$, em relação aos animais assentados na parede do tanque. Os resultados mostram que a eficiência do coletor é dependente da metodologia de preparação das larvas para assentamento e o material usado no coletor.

\section{ACKNOWLEDGEMENTS}

The authors gratefully acknowledge the financial support by CAPES (scholarship graduate grant).

\section{REFERENCES}

Alfaro, A. C. (2005), Effect of water flow and oxygen concentration on early settlement of the New Zealand green-lipped mussel, Perna canaliculus. Aquaculture, 245, 285-294.

Alfaro, A. C. and Jeffs, A. G. (2003), Variability in mussel settlement on suspended ropes placed at Ahipara Bay, Northland, New Zealand. Aquaculture, 216, 115-126.

Araújo, A.A.B. (1994), Obtenção de sementes de mexilhão Perna perna (Bivalvia. Mytilidae) em estruturas manufaturadas na Ponta do Papagaio, Palhoça - Santa Catarina. Master Thesis, Universidade Federal de Santa Catarina, Florianópolis, Brazil.

Bayne, B. (1964), Primary and secondary settlement in Mytilus edulis L. (Mollusca). Journal of Animal Ecology, 33, 513-523. 
Buchanan, S. and Babcock, R. (1997), Primary and secondary settlement by the greenshell mussel Perna canaliculus. Journal of Shellfish Research, 16, 7176.

Cáceres-Martínez, J., Robledo, J. A. F. and Figueras, A. (1993), Settlement of mussels Mytilus galloprovincialis on a exposed rocky shore in Ría de Vigo, NW Spain. Marine Ecology Progress Series, 93, 195-198.

Cáceres-Martínez, J., Robledo, J. A. F. and Figueras, A. (1994), Settlement and post-larvae behaviour of Mytilus galloprovincialis: field and laboratory experiments. Marine Ecology Progress Series, 112, 107-117.

Eyster, L. S. and Pechenik, J. A. (1987), Attachment of Mytilus edulis L. larvae on algal and byssal filaments is enhanced by water agitation. Journal of Experimental Marine Biology and Ecology, 114, 99110.

FAO (2004), Hatchery culture of bivalves. Inland Water FAO Fisheries Department. Rome, Italy.

Farias, T. Z. (2005), Assentamento de larvas de mexilhão Perna perna (L.) em condições de laboratório. Master Thesis, Universidade Federal de Santa Catarina, Florianópolis, Brazil.

Ferreira, J. F. and Magalhães, A. R. M. (2004), Cultivo de mexilhões. In-Aqüicultura: experiências brasileiras, orgs. Poli, C.R.; Poli, A. T. B.; Andreatta, E.; Beltrame, E.. Multifatorial editora. Florianópolis, 221-250.

Harvey, M. and Bourget, E. (1995), Experimental evidence of passive accumulation of marine bivalve larvae on filamentous epibenthic structures. Limnology and Oceanography, 40, 94-104.

Helson, J. G. and Gardner, J. P. A. (2004), Contrasting patterns of mussel abundance at neighbouring sites: does recruitment limitation explain the absence of mussels on Cook Strait (New Zealand) shores? Journal of Experimental Marine Biology and Ecology, 312, 285-298.

Holiday, J. E., Allan, G. L. and Frances, J. (1991), Cold storage effects on setting of larvae of the Sydney rock oyster, Saccostrea commercialis, and the Pacific oyster, Crassostrea gigas. Aquaculture, 92, 179-185.

Hunt, H. L. and Scheibling, R. E. (1997), Role of early post-settlement mortality in recruitment of benthic marine invertebrates. Marine Ecology Progress Series, 155, 269-301.

Lasiak, T. A. and Barnard, T. C. E. (1995), Recruitment of the brown mussel Perna perna onto natural substrata: a refutation of the primary/secondary settlement hypothesis. Marine Ecology Progress Series, 120, 147-153.
Lunetta, J. E. (1969), Fisiologia da reprodução dos mexilhões (Mytilus perna - Mollusca: Lamellibranchia). Boletim de Zoologia e Biologia Marinha., 26, 33-112.

Marques, H. L. A. (1987), Estudo preliminar sobre a época de captação de jovens de mexilhão Perna perna (Linnaeus, 1758) em coletores artificiais na região de Ubatuba, São Paulo, Brasil. Boletim do Instituto de Pesca, São Paulo, 14, 25-34.

Pechenik, J. A., Eyster, L. S., Widdows, J. and Bayne, B. L. (1990), The influence of food concentration and temperature on growth and morphological differentiation of blue mussel Mytilus edulis L. larvae. Journal of Experimental Marine Biology and Ecology, 136, 47-64.

Pulfrich, A. (1996), Attachment and settlement of postlarval mussels (Mytilus edulis 1.) in the Schleswlgholstein Wadden sea. Journal of Sea Research., 36, 239-250.

Rajagopal, S., Venugopalan, V. P., Nair, K. V. K., Van der Velde, G. and Jenner, H. A. (1998), Settlement and growth of the green mussel Perna viridis (L.) in coastal waters: influence of water velocity. Aquatic Ecology, 32, 313-322.

Ramírez, S. C. and Cáceres-Martínez. (1999), Settlement of the blue mussel Mitylus galloprovincialis Lamarck on artificial substrates in Bahía de Todos os Santos B. C., México. Journal of Shellfish Research, 18, 33-39.

Seed, R. 1976. Ecology. In- Bayne, B. L. (1976), Marine mussel: their ecology and physiology, L. Cambridge University Press: Cambridge, pp. 13-65

Snodden, L. M. and Roberts, D. (1997), Reproductive patterns and tidal effects on spat settlement of Mytilus edulis populations in Dundrum Bay, Northern Ireland. Journal of the Marine Biological Association U. K., 77, 229-243.

Trevelyan, G. A. (1991), Aquacultural ecology of hatchery-produced juvenile bay mussels, Mytilus edulis L. PhD Dissertation, University of California, California, United States of America.

Vooys, C. G. N. (1999), Numbers of larvae and primary plantigrades of the mussel Mytilus edulis in the western Dutch Wadden Sea. Journal of Sea Research, 41, 189-201.

Walter, U. and Liebezeit, G. (2003), Efficiency of blue mussel (Mytilus edulis) spat collectors in highly dynamic tidal environments of the Lower Saxonian coast (southern North Sea). Biomolecular Engineering, 20, 407-411. 